\title{
Tax Evasion in Small and Micro Greek Firms in the Light of the Economic Recession
}

\author{
George Drogalas ${ }^{1}$, Evgenia Anagnostopoulou', Michail Pazarskis², Sotirios Galeas ${ }^{3}$ \\ ${ }^{1}$ Department of Business Administration, University of Macedonia, Thessaloniki, Greece \\ ${ }^{2}$ Department of Accounting \& Finance, Technological Educational Institute of Central Macedonia, Serres, Greece \\ ${ }^{3}$ Ministry of Finance, Kilkis, Greece \\ Email:*drogalas@uom.gr
}

How to cite this paper: Drogalas, G. Anagnostopoulou, E., Pazarskis, M. and Galeas, S. (2018) Tax Evasion in Small and Micro Greek Firms in the Light of the Economic Recession. Theoretical Economics Letters, 8, 135-146.

https://doi.org/10.4236/tel.2018.82009

Received: December 24, 2017

Accepted: February 3, 2018

Published: February 6, 2018

Copyright (C) 2018 by authors and Scientific Research Publishing Inc. This work is licensed under the Creative Commons Attribution International License (CC BY-NC 4.0).

http://creativecommons.org/licenses/by/4.0/

\section{Open Access}

\begin{abstract}
Reducing tax evasion has been among the top priorities of the Greek public administration especially during the last years of the economic recession. The purpose of this study is to examine the level of tax evasion of Greek small and micro firms and how it is affected by the inefficiency of the Public Administration, the negative economic environment and various negative psychological factors. We examine different economic sectors but focus on the retail sale of goods and services. The research hypotheses, regarding the relationship between tax evasion and the above factors are tested through a multiple linear regression model developed for this study. Factor analysis was used to construct the variables used in our model. Our results show that tax evasion is positively affected by the inefficiency of public administration in determining the appropriate rate of tax, in simplifying the complexity of laws and establishing an effective justice system. Finally, the hypothesis regarding the relationship between tax evasion and economic factors is rejected while the hypothesis regarding the relationship between tax evasion and psychological factors is marginally accepted.
\end{abstract}

\section{Keywords}

Tax Evasion, Small and Micro Firms, Public Administration, Economic Recession

\section{Introduction}

Tackling tax evasion has been among the top priorities of the Greek public administration during the last thirty years and nowadays, in the light of the latest economic crisis, it has become an imperative. [1] has estimated that curbing tax 
evasion could increase public revenue by at least $3.8 \%$ of GDP, a rate equivalent to more than one third of the required fiscal adjustment of the first 2010 Stability Program. However, the adverse effects of tax evasion are not limited solely to raising public revenue. The unequal distribution of tax burden as well as the high tax rates, which are both directly affected by tax evasion, has also an adverse impact on economic growth. Additionally, tax evasion in the long run leads to rising deficit and higher interest rates, inefficient redistribution policy, citizens' reluctance to meet their tax obligations, distortions in the economy, reduction in private investment, loss in competitiveness of healthy businesses and, hence, a reduction in the competitiveness of the entire national economy [2].

The aim of this research is to study the relationship between tax evasion in small and micro business and economic factors related to tax administration, the tax legal framework, internal psychological factors and external structural factors. We will also determine the level of tax evasion in small and micro business and identify the differences between activity sectors. Our study contributes to international research regarding tax evasion by focusing on micro and small firms in retail trading, a sector which has not been thoroughly examined by academic literature. The main constrain of this study is that it examines a specific geographic area, that of northern Greece, which does not allow us to generalize our results for other countries. However, the fact that the research takes place in a country which has been in recession during the last six years, makes its results important for policy makers, since it provides insight on public policy that could be adopted in order to tackle the phenomenon of tax evasion. The structure of this study includes the bibliographic overview and the formulation of the research hypotheses, the clarification of the selected research methodology, the presentation of the demographic data of our research sample and our research results and, finally, the last section includes a discussion of the findings of our research, our limitations and suggestions for future research.

\section{Literature Review and Hypotheses Development}

Tax evasion is defined as any unlawful act or omission which results in the avoidance of the payment of any relevant tax liability. It is worth mentioning that several researchers, instead of the term tax evasion, use the most neutral term, tax noncompliance. In their research, [3] estimated that the rate of tax evasion was $26 \%$ and the corresponding rate of undeclared income was $10 \%$. Moreover, they consider it highly likely that the actual rates of tax evasion might be far higher than those estimated on their work, for two main reasons: the existence of a number of taxpayers who do not submit a tax return statement at all, and the fact that respondents in direct questions regarding family budget tend to underestimate their income more than they do in their actual tax statements.

According to [1], income derived from non-employment services was identified as the main "culprit" for the limited Greek tax base. Moreover, the structure 
of the Greek economy which consists mainly by small businesses and self-employed individuals is also considered to be one of the main reasons behind this tax evasion. The amount of undeclared income was estimated at $20 \%$ of GDP (or €50 billion in 2010 prices), mainly originating from self-employment.

In a report of [4] complexity of the tax system, the structure of the Greek economy and the organizational weaknesses of the tax collection service, are among the main reasons for the existence of extensive tax evasion. Among the proposals made were: the simplification of the legislative framework, tightening penalties on corruption matters, interconnection of individual information systems of Public Administration and strengthening tax consciousness. [5] addresses the impact of the intensification of tax audits and a more effective tax collection system on tax compliance. Specifically, he estimates that an increase of $1 \%$ on partial on-the-spot audits would lead to a reduction of $0.3 \%$ to $0.4 \%$ of tax non-compliance. Finally, he shows that the improvement of tax administration in these areas would have a positive impact on curbing tax evasion.

By using a methodology based on data obtained from the credit rating process of a domestic banking institution, [6] estimate the undeclared income of small private businesses for the 2006-2009 period, at a rate of $43 \%$ - 45\%, meaning that, for 2009 alone, the undeclared income had reached a level of around $€ 28.2$ billion, and tax evasion around $€ 11$ billion. According to the same study, freelance professionals emerge as the ones with the highest propensity to tax evasion. In the study of [2], complexity of the tax system is mentioned as a major cause for the expansion of tax evasion. Other causes include the increase of the tax burden, the lack of political will, corruption in the state mechanism and technological causes (lack of e-tax administration). Particular reference is made to the organizational and functional problems of the tax mechanism, in conjunction with the increased bureaucracy. At the same time, the problem is exacerbated by inadequate staff coordination, lack of education and lack of incentives. Similar remarks are made by [7] study as well, which characterizes manpower in tax administration aged, poorly trained in control and enforcement issues and also underpaid.

Contrary to the Greek literature, which is rather limited, international literature has examined the subject of tax evasion on multiple levels. [8], based on previous surveys on the underground economy have calculated the amount of tax evasion, as a percentage of GDP, in 38 OECD countries (including Greece) for the 1999-2010 period. They conclude that tax evasion in Greece ranges above the average levels, but in no case, does the country rank among the first places. [9], find that both economic and non-economic factors (detection and imposition of penalties, level of tax rates, government provision of public goods and services, overestimation of the probability to get subjected to audit on the part of the individuals, and social rules) play an active part regarding tax compliance. Moreover, [10] examines the impact of justice and impartiality on reducing tax evasion. In particular, he concludes that perceived justice has a positive effect on taxpayers and leads them to avoid tax noncompliance. This remark emerges 
both due to economic reasons, since the quality and quantity of public goods produced as a result of good administration increase individual private income, and due to psychological reasons, since, in a fair system, tax evasion takes on a heavy negative burden of recklessness in the citizens' conscience, while tax evading citizens are automatically stigmatized by society as a whole.

In their study on tax evasion in Switzerland [11], find that there is a positive correlation between tax non-compliance and marginal tax rates as well as inflation, and a negative correlation to audit probability. Moreover, no apparent influence is noted regarding the level of penalties. [12] detects a positive link between tax ethics and social capital, political participation and immigration. On the contrary, a negative correlation is found between tax ethics and dissatisfaction, and the quality of public services and between tax ethics and unemployment. Other studies associate tax evasion with political uncertainty (Katz and Owen, 2013), with uncertainty resulting from government decisions that maximize the risks in economic and tax decisions of individuals [9], or with cultural and national factors [13] [14].

Based on the review of the literature presented above, it appears that tax noncompliance is a phenomenon particularly difficult to detect and evaluate. However, regardless of the tactics and the methodology chosen by each researcher, and the fact that the extent of this phenomenon varies, depending on the country, it is concluded that the level of tax evasion constitutes a matter of great importance, and that its expansion is a matter of concern to the scientific community, the government officials, as well as the public opinion.

Especially in the case of Greece-which has been trapped for years in the spiral of an economic recession-it is commonly accepted that curbing tax evasion would directly lead to particularly positive financial and non-financial effects, such as reduction of nominal tax rates, reviving growth, increasing social expenditure, reducing social inequalities. Finally, it is also shown that tax evasion is complex, and is determined by a number of factors that may be economic, political, structural, legal/procedural, administrative and organizational, social and psychological. Based on the above, research hypotheses are formulated as follows:

H1: There is a positive relationship between tax evasion and public administration inefficiency.

$\mathrm{H} 2$ : There is a positive relationship between tax evasion and adverse economic factors.

H3: There is a positive relationship between tax evasion and adverse psychological factors.

\section{Research Methodology}

Regarding the target population selected for the survey, we used accountants who work either as freelancers or as employees in small and micro firms and public sector servants employed in the tax administration agency. The target population resided in the geographical region of northern Greece. The metho- 
dology used in this paper was based on the use of a close-ended questionnaire which consists of three sub-sections. The first includes questions about demographic characteristics of the respondent (sex, workplace, specialty, work experience, age and educational level). The second part consists of eight questions which ask the respondent to assess the level of tax evasion in various professional sectors at a seven-point Likert scale. The third part consists of twelve questions which measure the level of economic conditions, the organizational inefficiency of tax administration and psychological factors related to the sense of injustice also at a seven-point Likert scale.

A total of 163 questionnaires were distributed (78 in the private sector and 85 in the public sector) of which 122 were returned (75\% response rate). Among the participants, 66 were women (54.1\%) and 56 men (45.9\%). $49.2 \%$ of the participants work in the private sector and $50.8 \%$ in the public sector. Regarding the professional status, 20 of the participants are tax office officials (16.4\%), 42 work as public sector auditors (34.4\%), 32 are freelancers (26.2\%) and 28 are private employees (23\%). In terms of work experience, 19 of the participants have less than 5 years of work experience (15.6\%), 57 participants have from 6 to 15 years (46.7\%) and 46 of them have over 16 years (37.7\%). $25.4 \%$ of the participants are between 25 to 35 years old, $48.4 \%$ of them are between 36 and 50 years old while $26.2 \%$ are over 51 years old. Regarding the level of education of the participants, 17 of them are secondary school graduates (13.9\%), 80 of them are graduates of higher education (65.6\%) and 25 have a postgraduate degree (20.5\%). Table 1 below, summarizes the demographic data of the sample.

\section{Survey Results}

\subsection{Factor Analysis}

In order to examine the validity of our research instrument factor analysis was performed on the questions which are components of both the dependent and the independent variables. The factor analysis results for the components of the dependent variable are presented in the Table 2. In order to achieve a more valid structure, questions/variables with a factor loading close to 0.6 of above were included in each factor. The value for the Kaiser-Meyer-Olkin (KMO) measure is $0.811>0.7$. The value of the determinant of the correlation table is $0.023>$ 0.00001 .

Two dependent variables were constructed, one of which represents sectors that focus on the retail trade and provision of services and was named Retail Business Tax Evasion Indicator (RBTEI). The second represents wholesale-focused businesses and was named Wholesaling Business Tax Evasion Indicator (WBTEI).

The final results of the factor analysis regarding the questions of the independent variables are presented in Table 3. In order to achieve a more valid structure, variables with a factor load more than 0.6 were included in each factor. The value for the Kaiser-Meyer-Olkin measure is $0.761>0.7$. The value of the determinant of the correlation table is $0.005>0.00001$. 
Table 1. Sample demographics.

\begin{tabular}{|c|c|c|}
\hline Demographic data & Frequency & Percentage \% \\
\hline \multicolumn{3}{|c|}{ Sex } \\
\hline Male & 56 & $45.9 \%$ \\
\hline Female & 66 & $54.1 \%$ \\
\hline \multicolumn{3}{|c|}{ Sector } \\
\hline Private & 60 & $49.2 \%$ \\
\hline Public & 62 & $50.8 \%$ \\
\hline \multicolumn{3}{|c|}{ Profession } \\
\hline Tax official & 20 & $16.4 \%$ \\
\hline Public Auditor & 42 & $34.4 \%$ \\
\hline Accountant (Freelancer) & 32 & $26.2 \%$ \\
\hline Accountant (Private employee) & 28 & $23 \%$ \\
\hline \multicolumn{3}{|c|}{ Work experience } \\
\hline 0 - 5 years & 19 & $15.6 \%$ \\
\hline $6-15$ years & 57 & $46.7 \%$ \\
\hline Over 16 years & 46 & $37.7 \%$ \\
\hline \multicolumn{3}{|c|}{ Age } \\
\hline 25 - 35 years old & 31 & $25.4 \%$ \\
\hline 36 - 50 years old & 59 & $48.4 \%$ \\
\hline $51+$ & 32 & $26.2 \%$ \\
\hline \multicolumn{3}{|c|}{ Level of education } \\
\hline Secondary education & 17 & $13.9 \%$ \\
\hline Higher education & 80 & $65.6 \%$ \\
\hline Postgraduate degree & 25 & $20.5 \%$ \\
\hline
\end{tabular}

Table 2. Factor analysis results for the dependent variables.

\begin{tabular}{|c|c|c|}
\hline \multicolumn{3}{|c|}{ Rotated Factor Matrix } \\
\hline & \multicolumn{2}{|c|}{ Factor } \\
\hline & 1 & 2 \\
\hline Scientists-Artists & 0.756 & \\
\hline Services & 0.724 & \\
\hline Medical Services & 0.683 & \\
\hline Retail trade & 0.610 & \\
\hline Catering & 0.584 & \\
\hline Manufacturing & & 0.975 \\
\hline Wholesaling & & 0.615 \\
\hline Primary sector & & 0.569 \\
\hline
\end{tabular}

Extraction Method: maximum likelihood. Rotation Method: Varimax with Kaiser normalization. ${ }^{*}=$ Rotation converged in 3 iterations. 
Table 3. Factor analysis results for the independent variables.

\begin{tabular}{|c|c|c|c|}
\hline \multicolumn{4}{|c|}{ Rotated Factor Matrix } \\
\hline \multirow{2}{*}{ Questionnaire Items } & \multicolumn{3}{|c|}{ Component } \\
\hline & 1 & 2 & 3 \\
\hline Increased rate of direct taxes & 0.877 & & \\
\hline Increased rate of indirect taxes & 0.87 & & \\
\hline Economic downturn & 0.753 & & \\
\hline Increased rate of public insurance payments & 0.643 & & \\
\hline Understaffing of tax agency & & 0.777 & \\
\hline Control system weakness & & 0.712 & \\
\hline Increased organizational problems & & 0.697 & \\
\hline Inefficient justice system & & 0.696 & \\
\hline Law complexity & & 0.619 & \\
\hline Inadequate provision of public services & & & 0.842 \\
\hline Injustice of the tax system & & & 0.806 \\
\hline Lack of political will & & & 0.71 \\
\hline
\end{tabular}

Three independent were constructed as described below: Negative Economic Factors, concerning financial burdens on enterprises, Public Administration Inefficiency, concerning the weaknesses of the taxation system, and Negative Psychological Factors, including the questions regarding the lack of justification, subjective feeling of injustice and sense of lack of political will. The descriptive statistics of the two new dependent variables and the three new independent with the questions that consist them are presented in Table 4 and Table 5.

In addition, a reliability analysis was performed to test the consistency of the constructed variables. The internal consistency was checked by using the Cronbach's alpha index. The constructs have values of 0.772 for the WBTEI variable, 0.843 for the WBTEI variable, 0.810 for the NEF variable, 0.798 for the PAI variable and 0.790 for the NPF variable (all the Cronbach's alpha indexes get values $>0.7$ indicating the internal consistency of the constructed variables).

\subsection{Regression Analysis}

Table 6 shows the correlations between the dependent and the independent variables which were constructed after the factor analysis.

We should first point out that the regression analysis with the use of the Rate of Tax Evasion of Wholesaling Businesses (WBTEI) as a dependent variable did not yield any appreciable results $(\mathrm{R} 2=0.026, \mathrm{R}$ adjusted $=-0.007)$ indicating a very low interpretive capacity of the model.

In order to test our research hypotheses, a model of multiple linear regression was developed in the following form: 
Table 4. Descriptive statistics of the independent variables.

\begin{tabular}{|c|c|c|c|c|c|c|c|c|}
\hline \multirow{2}{*}{\multicolumn{2}{|c|}{$\begin{array}{c}\text { Structure and Items } \\
\text { The degree of tax evasion of } \\
\text { businesses from } 1 \text { (not at all) to } \\
7 \text { (a great extent) }\end{array}$}} & \multicolumn{7}{|c|}{ Frequency percentage $\%$} \\
\hline & & 1 & 2 & 3 & 4 & 5 & 6 & 7 \\
\hline \multirow{3}{*}{$\begin{array}{c}\text { Retail } \\
\text { Business Tax } \\
\text { Evasion } \\
\text { Indicator } \\
\text { (RBTEI) }\end{array}$} & Primary sector & $\begin{array}{c}2 \\
1.6 \%\end{array}$ & $\begin{array}{c}29 \\
23.8 \%\end{array}$ & $\begin{array}{c}25 \\
20.5 \%\end{array}$ & $\begin{array}{c}22 \\
18.8 \%\end{array}$ & $\begin{array}{c}28 \\
23 \%\end{array}$ & $\begin{array}{c}15 \\
12.3 \%\end{array}$ & $\begin{array}{c}1 \\
0.8 \%\end{array}$ \\
\hline & Manufacturing & $\begin{array}{c}3 \\
2.5 \%\end{array}$ & $\begin{array}{c}27 \\
22.1 \%\end{array}$ & $\begin{array}{c}27 \\
22.1 \%\end{array}$ & $\begin{array}{c}38 \\
31.1 \%\end{array}$ & $\begin{array}{c}15 \\
12.3 \%\end{array}$ & $\begin{array}{c}12 \\
9.8 \%\end{array}$ & $\begin{array}{c}0 \\
0 \%\end{array}$ \\
\hline & Wholesaling & $\begin{array}{c}1 \\
0.8 \%\end{array}$ & $\begin{array}{c}31 \\
25.4 \%\end{array}$ & $\begin{array}{c}32 \\
26.2 \%\end{array}$ & $\begin{array}{c}26 \% \\
21.3 \%\end{array}$ & $\begin{array}{c}22 \\
18 \%\end{array}$ & $\begin{array}{c}10 \\
8.2 \%\end{array}$ & $\begin{array}{c}0 \\
0 \%\end{array}$ \\
\hline \multirow{5}{*}{$\begin{array}{c}\text { Wholesaling } \\
\text { Business Tax } \\
\text { Evasion } \\
\text { Indicator } \\
\text { (WBTEI) }\end{array}$} & Retail trading & $\begin{array}{c}0 \\
0 \%\end{array}$ & $\begin{array}{c}8 \\
6.6 \%\end{array}$ & $\begin{array}{c}21 \\
17.2 \%\end{array}$ & $\begin{array}{c}36 \\
29.5 \%\end{array}$ & $\begin{array}{c}32 \\
26.2 \%\end{array}$ & $\begin{array}{c}24 \\
19.7 \%\end{array}$ & $\begin{array}{c}1 \\
0.8 \%\end{array}$ \\
\hline & Catering & $\begin{array}{c}0 \\
0 \%\end{array}$ & $\begin{array}{c}2 \\
1.6 \%\end{array}$ & $\begin{array}{c}18 \\
14.8 \%\end{array}$ & $\begin{array}{c}30 \\
24.6 \%\end{array}$ & $\begin{array}{c}39 \\
32 \%\end{array}$ & $\begin{array}{c}30 \\
24.6 \%\end{array}$ & $\begin{array}{c}3 \\
2.5 \%\end{array}$ \\
\hline & Scientists-artists & $\begin{array}{c}0 \\
0 \%\end{array}$ & $\begin{array}{c}7 \\
5.7 \%\end{array}$ & $\begin{array}{c}15 \\
12.3 \%\end{array}$ & $\begin{array}{c}23 \\
18.9 \%\end{array}$ & $\begin{array}{c}28 \\
23 \%\end{array}$ & $\begin{array}{c}47 \\
38.5 \%\end{array}$ & $\begin{array}{c}2 \\
1.6 \%\end{array}$ \\
\hline & Services & $\begin{array}{c}0 \\
0 \%\end{array}$ & $\begin{array}{c}14 \\
11.5 \%\end{array}$ & $\begin{array}{c}20 \\
16.4 \%\end{array}$ & $\begin{array}{c}26 \\
21.3 \%\end{array}$ & $\begin{array}{c}32 \\
26.2 \%\end{array}$ & $\begin{array}{c}30 \\
24.6 \%\end{array}$ & $\begin{array}{c}0 \\
0 \%\end{array}$ \\
\hline & $\begin{array}{c}\text { Medical } \\
\text { professions }\end{array}$ & $\begin{array}{c}0 \\
0 \%\end{array}$ & $\begin{array}{c}5 \\
4.1 \%\end{array}$ & $\begin{array}{c}15 \\
12.3 \%\end{array}$ & $\begin{array}{c}21 \\
17.2 \%\end{array}$ & $\begin{array}{c}33 \\
27 \%\end{array}$ & $\begin{array}{c}44 \\
36.1 \%\end{array}$ & $\begin{array}{c}4 \\
3.3 \%\end{array}$ \\
\hline
\end{tabular}

RBTEI $=b_{0}+b_{1}$ PAI $+b_{2} N E F+b_{3} \mathrm{NPF}+e_{i}$ where:

RBTEI $=$ Rate of Tax Evasion of Retail Trading Businesses.

PAI $=$ Public Administration Inefficiency.

$\mathrm{NEF}=$ Negative Economic factors.

$\mathrm{NPF}=$ Negative Psychological factors.

$\mathrm{e}_{\mathrm{i}}=$ error term

The regression analysis results for the developed model are listed (Table 7).

\subsection{Discussion of Findings}

Regarding the level of tax evasion, the answers resulted in a total average of 4.27 which can be interpreted that small and micro firms declare only half of their actual income. The estimated rate in this study is almost the same with the results presented by [6]. Regarding the acceptance of the research hypotheses on the relationship between the inadequacy of the public administration and the rate of tax evasion of the retail trading businesses, it consistent with the conclusions of [2] [4] [6] [15] [16] [17]. Regarding the correlation of the tax evasion with psychological factors (a research case which has been marginally accepted), there is a clear tendency of acceptance in both domestic and international literature. [2] [10] [12] [16] [17] [18], all of them argue for the link between tax evasion and psychological factors.

However, the rejection of the hypotheses regarding the relationship between tax evasion and negative economic factors contradicts with many earlier studies. Only [19] argues against the opinion that a large reduction in tax rates will also lead to a reduction of tax evasion. On the contrary, [2] [11] [16] [17] [18] link 
Table 5. Descriptive statistics of the dependent variables.

\begin{tabular}{|c|c|c|c|c|c|c|c|c|}
\hline Structure & and Items & & & Freque & cy perce & tage \% & & \\
\hline $\begin{array}{r}\text { The increase in ta } \\
\text { caused by the } \\
1 \text { (totally di } \\
\text { (absolute }\end{array}$ & $\begin{array}{l}\mathrm{x} \text { evasion is being } \\
\text { following... } \\
\text { sagree) to } 7 \\
\text { ly agree) }\end{array}$ & 1 & 2 & 3 & 4 & 5 & 6 & 7 \\
\hline & Economic & 2 & 8 & 21 & 34 & 32 & 21 & 4 \\
\hline & downturn & $1.6 \%$ & $6.6 \%$ & $17.2 \%$ & $27.9 \%$ & $26.2 \%$ & $17.2 \%$ & $3.3 \%$ \\
\hline & Increased rate & 0 & 5 & 5 & 21 & 42 & 35 & 14 \\
\hline Negative & of direct taxes & $0 \%$ & $4.1 \%$ & $4.1 \%$ & $17.2 \%$ & $34.4 \%$ & $28.7 \%$ & $11.5 \%$ \\
\hline Economic & Increased rate & 0 & 6 & 6 & 22 & 36 & 33 & 19 \\
\hline Factors & of indirect taxes & $0 \%$ & $4.9 \%$ & $4.9 \%$ & $18 \%$ & $29.5 \%$ & $27 \%$ & $15.6 \%$ \\
\hline (NEF) & Increased rate & & & & & & & \\
\hline & of public & 1 & 13 & 14 & 30 & 32 & 21 & 11 \\
\hline & $\begin{array}{l}\text { insurance } \\
\text { payments }\end{array}$ & $0.8 \%$ & $10.7 \%$ & $11.5 \%$ & $24.6 \%$ & $26.2 \%$ & $17.2 \%$ & $9 \%$ \\
\hline & Understaffing & 1 & 5 & 12 & 41 & 25 & 29 & 9 \\
\hline & of tax agency & $0.8 \%$ & $4.1 \%$ & $9.8 \%$ & $33.6 \%$ & $20.5 \%$ & $23.8 \%$ & $7.4 \%$ \\
\hline & Increased & 0 & 11 & 32 & 29 & 25 & 17 & 8 \\
\hline Public & $\begin{array}{l}\text { organizational } \\
\text { problems }\end{array}$ & $0 \%$ & $9 \%$ & $26.2 \%$ & $23.8 \%$ & $20.5 \%$ & $13.9 \%$ & $6.6 \%$ \\
\hline Administration & Control system & 0 & 6 & 21 & 36 & 20 & 33 & 6 \\
\hline Inefficiency & weakness & $0 \%$ & $4.9 \%$ & $17.2 \%$ & $29.5 \%$ & $16.4 \%$ & $27 \%$ & $4.9 \%$ \\
\hline & Inefficient & 0 & 6 & 24 & 38 & 26 & 24 & 4 \\
\hline & justice system & $0 \%$ & $4.9 \%$ & $19.7 \%$ & $31.1 \%$ & $21.3 \%$ & $19.7 \%$ & $3.3 \%$ \\
\hline & I & 0 & 8 & 20 & 26 & 23 & 38 & 7 \\
\hline & & $0 \%$ & $6.6 \%$ & $16.4 \%$ & $21.3 \%$ & $18.9 \%$ & $31.1 \%$ & $5.7 \%$ \\
\hline & Inadequate & 0 & 3 & 9 & 17 & 33 & 45 & 15 \\
\hline Negative & $\begin{array}{l}\text { provision of } \\
\text { public services }\end{array}$ & $0 \%$ & $2.5 \%$ & $7.4 \%$ & $13.9 \%$ & $27 \%$ & $36.9 \%$ & $12.3 \%$ \\
\hline Psychological & Injustice of the & 0 & 3 & 14 & 34 & 28 & 36 & 7 \\
\hline Factors (NPF) & tax system & $0 \%$ & $2.5 \%$ & $11.5 \%$ & $27.9 \%$ & $23 \%$ & $29.5 \%$ & $5.7 \%$ \\
\hline & Lack of political & 1 & 0 & 7 & 22 & 28 & 39 & 25 \\
\hline & will & $0.8 \%$ & $0 \%$ & $5.7 \%$ & $18 \%$ & $23 \%$ & $32 \%$ & $20.5 \%$ \\
\hline
\end{tabular}

Table 6. Pearson's correlation matrix.

\begin{tabular}{cccccc}
\hline & RBTEI & WBTEI & NEF & PAI & NPF \\
\hline RBTEI & 1 & & & & \\
WBTEI & 0.046 & 1 & & & \\
NEF & 0.019 & -0.129 & 1 & 1 & \\
PAI & $0.223^{*}$ & 0.046 & 0 & 0 & 1 \\
NPF & 0.143 & -0.065 & 0 & 0 & \\
\hline
\end{tabular}

${ }^{*}$ Correlation is significant at the 0.05 level (2-tailed). ${ }^{*}$ Correlation is significant at the 0.01 level (2-tailed).

tax evasion to the level of the tax burden. A reasonable assumption that could be pointed out is that tax evasion is so deeply rooted in the Greek economy and society that whether the tax rates are high does not affect tax evasion. 
Table 7. Pearson's correlation matrix.

(a)

\begin{tabular}{cccccc}
\hline Model & \multicolumn{2}{c}{$\begin{array}{c}\text { Unstandardized } \\
\text { Coefficients }\end{array}$} & $\begin{array}{c}\text { Standardized } \\
\text { Coefficients }\end{array}$ & $\mathrm{t}$ & Sig. \\
\hline & $\mathrm{B}$ & Std. Error & Beta & & \\
\hline (Constant) & $1.83 \mathrm{E}-16$ & 0.076 & & 0 & 1 \\
NEF & 0.018 & 0.077 & 0.019 & 0.229 & 0.819 \\
PAI & 0.202 & 0.077 & 0.223 & 2.633 & 0.01 \\
NPF & 0.129 & 0.077 & 0.143 & 1.689 & 0.094 \\
\hline
\end{tabular}

a. Dependent Variable: RBTEI

(b)

\begin{tabular}{cccccc}
\hline \multicolumn{5}{c}{ Model Summary $^{\mathrm{b}}$} \\
\hline \multirow{2}{*}{ Model } & $\mathrm{R}$ & $\mathrm{R}$ Square & $\begin{array}{c}\text { Adjusted R } \\
\text { Square }\end{array}$ & $\begin{array}{c}\text { Std. Error of the } \\
\text { Estimate }\end{array}$ & Durbin-Watson \\
\hline 1 & $0.402^{\mathrm{a}}$ & 0.161 & 0.133 & 0.84190167 & 1.296 \\
\hline
\end{tabular}

a. Predictors: (Constant), NEF, NPF, PAI; b. Dependent Variable: RBTEI.

\section{Conclusions}

The current study provides data on the estimated level of tax evasion of small and micro business as well as a number of several factors such as inadequacy of public administration, negative economic factors and negative psychological factors. As the international experience also dictates-in order to tackle a complex, multilevel and dynamic problem, such as tax evasion, commitment, planning, resources, organization and continuous effort are needed. The simplification of the tax legislation is the first step. Policy makers must stop trying to cover all the possible peculiarities of each economic activity and concentrate on a simple and functional tax system.

The reorganization of business units with an aim to identify delinquent behaviors and the simultaneous use of modern technological infrastructure, especially an information system of risk analysis is also necessary. Finally, training and the skill development of the staff as well as the motivation combined with an effective assessment and control system can also be implemented in order to increase the efficiency and effectiveness of the tax administration.

It is also proposed to increase controls, especially at the level of preventive and temporary control, with the activation of a significant part of the human resources in this sector in order to create an impression for all enterprises that there is an increased possibility of detecting offending behaviors, by analogy of which [1] suggests. Sometimes-as the science of psychology suggests-the fear of punishment is more deterrent than the punishment itself.

In any case, the findings of this study should be examined under the light of certain constraints. The first constraint is of geographic type. Due to the fact that the survey was conducted in entities that are operating in a specific geographic 
area, the conclusions cannot be generalized to the whole population. A second constraint arises from the same methodology which was used, i.e. the method of collecting primary data by using questionnaires. Even though we carefully selected the target population, bias of the respondents is still among the limitations of our research, given the fact that the social background, the attitude and the prejudice of each respondent could affect the quality of our data. A third constraint concerns the research tool itself. It is essentially a prototype construction which has been compiled for the purposes of the present invention based on the findings of the bibliography and empirical data. It is up to the future researchers to adapt and enrich it in order to respond better to future primary data collection surveys.

\section{References}

[1] Mylonas, P., Magginas, N. and Pateli, E. (2010) What Are the Margins for Increasing PIT Revenue in the Greek Economy? National Bank of Greece. Monthly Macroeconomic Outlook, Greece.

http://air.euro2day.gr/media/files/945568MonthlyAprilMay_v8\%CE\%99\%CE\%99_ ZQ3AL.pdf

[2] Ernst \& Young (2016) Tax Evasion in Greece: Causes, Extent and Proposals. https://www.dianeosis.org/research/tax-evasion/

[3] Matsaganis, M. and Flevotomou, M. (2010) Distributional Implications of Tax Evasion in Greece. The Hellenic Observatory, London School of Economics and Political Science, 31, 1-40. http://eprints.lse.ac.uk/26074/1/GreeSE_No_31.pdf

[4] Bank of Greece (2011) Tax Evasion in Greece: A General Overview. Financial Bulletin of the Bank of Greece, 35, 15-26. http://www.bankofgreece.gr/BogEkdoseis/oikodelt201106.pdf

[5] Tagkalakis, A. (2014) Tax Administration Reforms and the Fight against Tax Evasion: Recent Evidence from Greece.

http://voxeu.org/article/tax-evasion-and-reforms-greece

[6] Artavanis, N., Morse, A. and Tsoutsoura, M. (2015) Measuring Income Tax Evasion using Bank Credit: Evidence from Greece. Chicago Booth Research Paper, 12-25, http://dx.doi.org/10.2139/ssrn.21095000

[7] International Monetary Fund (2013) Greece, Selected Issues. IMF Country Report, 13. https://www.imf.org/external/pubs/ft/scr/2013/cr13155.pdf

[8] Buehn, A. and Schneider, F. (2012) Size and Development of Tax Evasion in 38 OECD Countries: What Do We (Not) Know? Journal of Economics and Political Economy, 3, 1-11.

[9] Alm, J. (1988) Uncertain Tax Policies, Individual Behavior and Welfare. The American Economic Review, 78, 237-245.

[10] Falkinger, J. (1995) Tax Evasion, Consumption of Pubic Goods and Fairness. Journal of Economic Psychology, 16, 63-72. https://doi.org/10.1016/0167-4870(94)00038-C

[11] Pommerehne, W. and Weck-Hannemann, H. (1996) Tax Rates, Tax Administration and Income Tax Evasion in Switzerland. Public Choice, 88, 161-170. https://doi.org/10.1007/BF00130416

[12] Russo, F.F. (2013) Tax Morale and Tax Evasion Reports. Economics Letters, 121, 110-114. https://doi.org/10.1016/j.econlet.2013.07.004 
[13] Richardson, G. (2008) The Relationship between Culture and Tax Evasion across Countries: Additional Evidence and Extensions. Journal of International Accounting, Auditing and Taxation, 17, 67-78.

https://doi.org/10.1016/j.intaccaudtax.2008.07.002

[14] Tsakumis, G., Curatola, A. and Porcano, T. (2007) The Relation between National Cultural Dimensions and Tax Evasion. Journal of International Accounting, Auditing and Taxation, 16, 131-147. https://doi.org/10.1016/j.intaccaudtax.2007.06.004

[15] Kalyviannakis, K., Ksanthakis, M., Leventis, A., Manesiotis, V., Theodoropoulos, S., Trachanas, K. and Flesiopoulou, K. (1993) Tax Status, Shadow Economy and Tax Evasion in Greece. Papazisis, Athens.

[16] Kanellopoulos, K, Kousoulakos, I. and Rapanos, V. (1995) Shadow Economy and Tax Evasion: Measurements and Economic Impact. Center for Planning and Economic Research, Athens, 15.

[17] Tatsos, N. (2001) Shadow Economy and Tax Evasion in Greece. Papazisis, Athens.

[18] Alm, J., Sanchez, I. and De Juan, A. (1995) Economic and Noneconomic Factors in Tax Compliance. Kyklos, 48, 1-18.

https://doi.org/10.1111/j.1467-6435.1995.tb02312.x

[19] Katsios, S. (2006) The Shadow Economy and Corruption in Greece. South-Eastern Europe Journal of Economics, 1, 61-80. 